Journal of Social Sciences (COES\&RJ-JSS)

ISSN (E): 2305-9249 ISSN (P): 2305-9494

Publisher: Centre of Excellence for Scientific \& Research Journalism, COES\&RJ LLC

Online Publication Date: $\mathbf{1}^{\text {st }}$ October 2020

Online Issue: Volume 9, Number 4, October 2020

https://doi.org/10.25255/jss.2020.9.4.1520.1530

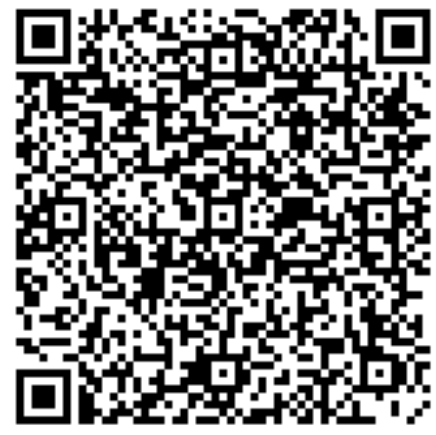

\title{
Linguistic Features' Variation in Translating Technical Texts
}

Abdel-Hameed Al-Awabdeh

Department of English Language and Literature

The University of Jordan, Aqaba, Jordan

Abstract:

This research examines the contribution of language variation in translating technical texts from English into Arabic language. It aims at analysing language variation, technical texts translation competence, creating subject field knowledge and generating authenticity in technical texts and translation setting. This study attempts to uncover problems that English language and literature students at the University of Jordan / Aqaba branch problems of translating technical texts. This qualitative research included 30 B.A students selected randomly from the Dept. of English Language and Literature at the University of Jordan. The results of the study revealed that literature students encountered many problems when translating technical texts, particularly when using two different varieties of English American / British into Arabic language. This research recommends that translators and professional in the field should be concerned with translating technical texts and include them in translation syllabi.

Keywords:

Translation, Technical Text, Genre, Strategies, Linguistic Features

\section{Citation:}

Al-Awabdeh, Abdel-Hameed (2020); Linguistic Features' Variation in Translating Technical Texts; Journal of Social Sciences (COES\&RJ-JSS), Vol.9, No.4, pp:15201530; https://doi.org/10.25255/jss.2020.9.4.1520.1530. 


\section{Introduction}

Translation is a practice that requires a lot of efforts. A translator should be qualified in the area so that he or she can translate diverse texts. So, an investigation is a noticeable element in translation. That is, translation process should preserve the data in the target text related to that of the source text without any gain or loss in the interpreted texts. There are several important features that add to the development of the translation process involving the target audience and text, source language, the cultural and the stylistic characteristic (Poiter and Karin 2007; Gorlee 2004).

There is no uncertainty that translation is a significant area of investigation for numerous determinations, in which the translation of technical terms is basically necessary by today's technical translator to face difficulties of one's national security setting (Schjoldoger, 2008).

But, there is an absence of standardizing technical terms which relate for both dialects and variations within the same language. This thoughtful condition propose an excessive trial for some technical translators when translating from the source language into the target language (Dyvik, 2004).

Generally, translation shows a great encounter for Arabic students majoring in English language and literature, in common (Basil and Mason, 1990). In the meantime, translating technical texts generates a lot of problems for English literature students, in precise. Amongst these difficulties, is that American and British technical texts are totally diverse. Such variance is activated by the difference in the American and British linguistic cultures.

This difference causes dissimilarity in the selected Arabic equivalence, presenting a state of misunderstanding for the technical translator (Poiter and Karin, 2007). Remarkably, neither the variances between American and British technical texts are investigated from a translation viewpoint, nor the difficulties encountered by Arabic English literature students learning this field is explored or searched. So, the objective of this study is to investigate the linguistic features' variation in translating technical texts.

\section{Literature Review}

English as foreign language learning has developed to be the most frequently used language in the world since the end of the Cold War. It has advanced to be very important for military services for many nations (Christiane, 2007). According to Hardwick (2000) the term translation may relate to many things. That is, it may refer to the general field of translation including the translation's product, text or process. He adds the definition of the tern translation associates 


\section{Linguistic Features' Variation in Translating Technical Texts}

with different types of translation such as intralingual, interlingual and intersemoitic.

Likewise, Munday (2001) states that, defining translation process is a main question that does not have an explicit answer in the field of translation; it is not the basic objective of this paper to explore the definition of translation, but it is significant to relate the definition of translation in this regard, provided that this paper is about an important aspect within the area of technical translation.

Schojoldager (2008) states that translation refers to the transfer process of information or knowledge takes place from one source texts into the target text. This means that there is a kind of replacement of source language (SL) materials by means of equivalent into the target language (TL).Trying to describe the term "technical translation", a diversity of related literature is reviewed and inspected so as to determine a clear view of technical translation as probable.

It refers to the process of translating basic technical composites / terms (Sharoff, 2006). The necessity for clarifying technical texts is the method by which any work of technical translation can accomplish its kernel. Trosborg (1997) points out that no matter how technical translation may be articulated its influences are certainly achieved through language. Technical translation is related to translating texts written in technical language that are different from any other kind of language.

\section{Research Questions}

This paper addresses the following study questions:

Q1. What is the problem that English language and literature students encounter when translating technical texts from English (British/ American) to Arabic language?

Q2. What language variation is experienced when literature students identify the sources and the target languages for that variation in the source/target language when translating technical terms?

Q3. What are the technical translation strategies implemented by literature students to translate technical texts?

\section{Research Objectives}

This study intends to achieve the following objectives:

i. To investigate problem that English language and literature students encounter when translating technical texts from English (British/ American) to Arabic language?

ii. To examine language variation are experienced when literature students identify the sources and the target languages for that variation in the source/target language when translating technical terms? 


\section{Journal of Social Sciences (COES\&RJ-JSS), 9(4), pp.1520-1530}

iii. To identify the technical translation strategies implemented by literature students to translate technical texts?

\section{Methodology}

This study used mixed mode design for being the most suitable technique in the analysis of social phenomena in their real contexts (Gay, Mills and Airasian 2009). This study was concerned with the problems that English language and literature students at the University of Jordan / Aqaba branch face when translating technical texts from English (British/ American) into Arabic. In order to achieve the objectives of this study, British / American English technical texts were used to find out language variations' problems and difficulties in the use of technical terms. The terms used in this process were categorized and their frequencies recorded throughout the selected technical texts. The technical terms experienced were analyzed according to the skills, knowledge and students' background. The researcher used Skopos Theory 1970 framework for analyzing the translated technical terms. The sample of the study included $4^{\text {th }}$ Year Jordanian English language and literature students at the University of Jordan/ Aqaba for the academic year 2019/2020.

Ethically, the participants' names and addresses were kept anonymous. The participants were encouraged to translate 6 English technical texts ( 3 were in British English / 3 were in American English) into Arabic. The texts were assigned to the students to be submitted to the researcher within an academic week period. Also, there were requested to identify the most generally used technical translation strategies in their translation process.

The participants were encouraged to spell out their technical texts' translation experience, and any technical terms problems that they encountered while translating such terms. In addition, the participants were requested to complete a list of questionnaire items investigating the technical terms that they attribute to the possibly difficult technical terms converted from the analysis of the assigned technical texts. Then, the 30 participants were interviewed to see their perception and reaction towards the translation of technical texts to reveal the difficulties that they encountered in assigning technical terms to the questionnaire items.

The analysis of the technical texts included textual analysis and elicitation of translated materials from the participants, gathering the questionnaire items and conducting interviews with the participants. The study was conducted at the Language Center at the University of Jordan in Aqaba in October / 2019. The sample of the study was selected randomly based on the researcher's 


\section{Linguistic Features' Variation in Translating Technical Texts}

background in the field. This facilitated the researcher gain participants' willingness and confidence to contribute to the study.

Enough consideration was paid by the researcher to choose target technical texts since this study was concerned with technical specialized terms. The assigned technical texts were appropriate, contemporary and suitable for participants' level and academic background. The data of the interviews were analyzed textually and the questionnaires were translated using SPSS in which the information were computed and reported.

\section{Discussion and Findings}

This study aims at investigating the problem of linguistic/ language variation in translating technical texts by English language and literature students at the University of Jordan / Aqaba Branch. It used Skopo's Theory (1970) and Schjoldoger Taxonomy (2008) in which they relate to the use of micro-strategies and macro-strategies. This is because this method was used by many scholars as stated in past literature, particularly to this type of texts. Though, it was potential to primarily source oriented macro-strategy technical texts oriented macrostrategy.

To address the research questions of the study, it was significant to examine what technical genre is, and the type of technical discourse is, propose that it is a genre. Further, it was important to examine how to describe and identify genres in relation to technical translation. This investigation will achieve a model that might be used to analyze and translate technical texts related to both target and source languages contexts, and by means of comparative analysis to reveal the language and linguistic variation in technical texts' translation genre conventions might be identified.

Also, it was significant to examine what technical texts' translation commonly refers to and what are the relevant approaches that associate to this field. By princely examining essential theoretical approaches, Skopo's Theory (1970) may be categorized, and then examine particularly those that relate to Skopo's analysis as presented by Schjoldager (2008), give the idea that this is a significant analysis for this research. This due to the inclusion of both theoretical concepts, in spite of the reality that this theory is criticized for not being practical and a pragmatic method to relate to translation and investigate translations. In addition, this method considers the difficulties of the cultural aspects not only within different language variation of the same language system but also inside the same the language varieties. The data was selected using criteria that confirmed that information is available and similar to both source and target language technical texts. The technical texts used for the purpose of this study 
were real and original, as the translation of the technical texts (target texts) may have been using any kind of technical genre transcript as their source language texts.

This is potential that source language texts may have various inconsistencies with the technical source texts used by English language and literature students at university level, and they have to be in the findings.

As far as the analysis of the findings is concerned, the results showed that all the participants in their technical texts' translation process used excessively microstrategies that included oblique and direct translation as the most widely used translation strategies.

Based on the analysis, it was found that all military texts' translation the most employed microstrategies was the direct translation, with the oblique translation as the second most common micorstrategy as shown in the following examples; when translating the electronic device "Mobile Phone" in British English which is literary "Cell Phone" in American English, using direct translation strategy, the translator experiences some problems in relation to which term be selected since there is a difference in their shades and nuance of meaning based on the use in their linguistic situation each UK or USA. That is, the word Cell Phone in the United States is different from that in the United Kingdom in which there are some criteria that differentiate the usage of the two terms based on the variation of the linguistic contexts. Table 1.1 in the next section displays some terms in American and British English and their translation in Arabic language:

Table 1.1: Examples of American and British English Terms / Variation

\begin{tabular}{|c|c|c|c|}
\hline & \multicolumn{2}{|c|}{ Technical Terms } & Field \\
\hline $\begin{array}{c}\text { American } \\
\text { English }\end{array}$ & Druggist & Cell Phone & Medicine \\
\hline $\begin{array}{c}\text { British } \\
\text { English }\end{array}$ & Chemist & Mobile Phone & $\begin{array}{c}\text { Electronic } \\
\text { Industry }\end{array}$ \\
\hline $\begin{array}{c}\text { Arabic } \\
\text { Language }\end{array}$ & $\begin{array}{c}\text { (SAIDALANI) } \\
\text { (ALHATEF AL }\end{array}$ & $\begin{array}{c}\text { Translation } \\
\text { (ALAHMOUL) }\end{array}$ & \\
\hline
\end{tabular}

As displayed in the table, it is observed that the word druggist / chemist / pharmacist which is used in (American and British) which is used in English to refer to a specific profession in the field of pharmacy and medicine indicates varied linguistic usages (pharmacy and medicine) whether in American or British English. Thus, such linguistic variation causes a problem for Arab English language and literature translators particularly when they attempt to translate 


\section{Linguistic Features' Variation in Translating Technical Texts}

that from English into Arabic where the word "Chemist; Druggist" صيدلاني" (SAIDALANI) is the only equivalent for one word in Arabic language in Jordanian Arabic unlike that of the United States or United Kingdom. This is an instance where the problems of direct translation makes the translator at a pace as which English equivalent to select when translating. This not the only problem that translator in this regard encounter when translating technical terms from English language into Arabic where one technical terms in a particular language variety may be used in a linguistic setting differently from another setting. Further, there were examples of paraphrasing and deletion in all technical terms translation but these were not general to influence the common impression of the technical translation. Furthermore, most of the deletion and few examples of substitutions and condensation, showed to be deliberate strategy.

Regarding cultural allusions, all of them translated. These cultural inferences used translated directly, while explication was used in other situations. The effect of rhetorical features was infrequently reproduced in technical translation, and this seemed in the setting when the connotative sense and the rhetorical influence where connected comprising some descriptions. When the rhetorical components, be determined by essentially on linguistic constituents or rhyme to make this influence, such effect was generally not produced. This presented that the technical translator did not retain a partiality for the rhetorical content but did for the connotative / denotative content. There were no comments for any deliberate attempts to reduce the formality of technical translations. This included the technical translations of rhetorical components and the cultural references that presented that there were no deliberate attempts to accept the influences of the technical target language contexts.

As shown in Table 1.1 previously, different technical terms were used in both British and American English. This was a totally explicit comment that the technical terms target text was a try to report as who translated what and when. With regard to the technical terms target texts there precise opinion about the detail that technical translation as being of other senders' communications. This means that these technical translations enclosed new senders and new receivers in a socially different communicative situations, where the goal was to document what another translator had interpreted to other assemblies in diverse cultural backgrounds.

This viewed technical translation entirely overt. Further, it presented an interesting variation in the overall communicative technical translation tenacity, from being native like in the source texts to being referential in the target texts. All of these conclusions presumed that the technical translators used approaches that are pertinent to the technical source texts at both word and sentence levels. 
It exhibited the word and sentence level technical translation, with the purpose specified to the semantic content of the word rather than the linguistic effect, but deliberately to translate idiomatically decorative Arabic.

Precisely, the findings indicate that there is an inclination by the English language and literature translators to use a common strategic method to how these technical source texts are translated in which such features approve very intensely with technical source-texts' oriented macro-strategies. This shows that literature translators (students) incline to greatly be influenced by on macrostrategies in their translation process equalled to that of micro-strategies.

This finding does not validate that all technical texts can be translated depending on this method. This is because there were some translations that associate with this research. To conclude, the findings of this study accept that there is an overall translation method that might be applied to translate technical texts, but the findings are essentially restricted to translations applied by technical translators / English language and literature students. Further, due to the restricted number of technical texts applied, the findings only expose a common strategic method.

In order to identify whether or not this method is common, it would be recommended to test a larger corpus of technical texts, as the conclusions of this study may only be generalized to technical translators in the field of English Language and Literature at the at the University of Jordan / Aqaba Branch in Jordan. The data was selected depending on criteria that delivered the availability and ease of judgement between the target and source technical texts. The selected translation texts are not genuine, as the translators could have been using any form of transcript as their source language text. This gives the prospect that the source language texts possess several inconsistencies with comparable source language texts used by the translators, and this should be reflected when conferring the results.

In connection with the final investigation of the data, it was established that in all the translation texts, the simple engaged micro strategy was literary translation, with the direct translation as the second most generally used strategy. The translators showed to encounter great difficulties in translating technical texts not only from American or British English texts in Arabic language, but also translating technical texts within the same language.

Thus, the findings presented that the translators faced problems in translating the same technical terms in the same language, as those terms indicated different meanings in diverse linguistic contexts. This displays that in some 


\section{Linguistic Features' Variation in Translating Technical Texts}

circumstances the translators felt that it is very perplexing whether to use American or British English technical terms. Also, the conclusions showed that the translators faced a high level of misunderstanding and complexities in translating applicable technical terms. When investigating the translated technical texts in which the target texts are related with source texts through the segments (82) found in all the texts, it was found 69 examples of what it would be categorized as examples of micro strategies recognized as direct translation. Further, it was found 11 examples of oblique translation, 6 examples of deletion, 5 examples of calque, 4 examples of explication, 3 examples of addition and 3 examples of condensation.

These micro-strategies can be clarified but as the determination of this study which is concerned to find it appropriate to just specify them. This displays that technical translators are identical and adjacent to the word level of the technical source target texts.

When translating from technical British English texts, the translator appears prospective to make his translation grounded on source-text oriented macrostrategies.

The configuration in these strategies and relevant features clarified in here expresses this. This also establishes a sense of understanding when considering the technical translation of the target texts, as it would be clear to any Arab reader of such technical text that it would be a technical translation of previous written technical texts in linguistically diverse settings. Figure 1.2 in the following section shows the similarity between the source text and the technical text in terms of using the micro-strategies in military translation. The results showed that $84 \%$ of the participants showed that they experience a difficult challenge in translating English language technical texts into Arabic language. Whilst $16 \%$ of them encountered no problem in translating those texts into Arabic language.

As perceived in the conclusion of the present research, it is observed that there are many technical translators who have an inclination to depend on the use of macro-strategies when translating related to that use of micro-strategies. Also, it was found out that $84 \%$ of the respondents see translating technical terms from English language (American and British) very perplexing and full of difficulties.

This is not only established at the level of diverse languages of the same linguistic setting such as American English and British English, but also at the level of the same language such as the use of technical terms within American English that differs from one place to another in different technical fields. 


\section{Journal of Social Sciences (COES\&RJ-JSS), 9(4), pp.1520-1530}

Therefore, the respondents indicated that one of the inspiring and difficult issues is the collection of which, what, when and how since the application of one technical term varies from that of other field despite of the point it is the same technical term varies in translation from one English varieties to another governed by the cultural genre and linguistic context.

\section{Conclusion}

It has been established that translating technical texts from English Language into Arabic language is very difficult for technical translators because of the cultural genre variances within the varieties of the same language and this may be even comprehended within the diversity of the same language such as American or British English.

This measure creates great complexities for these technical translators. In addition, it was found out that technical translators applied varied kinds of translation strategies to translate definite technical texts, but they depended mainly on macro-strategies as related to those of micro-strategies.

So, there should be a methodical technique for teaching technical translation such as that of Skopo and Schjoldager (2008) taxonomy or analysis of translation. This research endorses that further inquiries in the field of technical translation be directed in the future to inspect greater number of technical texts $s$ so that decision makers may take the essential measures.

\section{References}

DYVIK, H (2004). "Translation as Semantic Mirrors: From Parellel Corpus to WordNet". Language and Computers, 49 (1): 311-326, 2004.

FAWCETT, Peter. 1997. Translation and Language: Linguistic Theories Explained, Manchester: St. Jerson.

GAY, R. MILLS, G., and AIRASIAN, P. 2009. Educational Research Competencies for Analysis and Applications. Ninth Edition: Pearson International Edition.

GOLLINS, T and SANDERSON, M. 2001. "Improving Cross Language Retrieval with Triangulated Translation”. In SIGIR, 2001.

GORLEE, Di Li. 2004. On Translating Signs: Rodopi.

HARDWICK, Larna. 2000. Translating Words, Translating Cultures, London: Duckworth. 


\section{Linguistic Features' Variation in Translating Technical Texts}

HATIM, Basil and IAN, Mason. 1990. Discourse and the Translator. London: Longman.

HATIM, BASIL, and IAN, Mason. 1997. The Translator as Communicator. London: Routledge.

MUNDAY, Jeremy. 2001. Introducing Translating Studies- Theories and Applications. London: Routledge.

MUNDAY, Jeremy. 2005. Introducing Translation Studies- Theories and Applications. Routledge, Abingdon.

NORD, Christiane. 2007. Translation as a Powerful Activity-Functionalist Approaches Explained. St. Jerome Publishing, Manchester.

ROBINSON, Douglas. 2003. Becoming a Translator. An Introduction to the Theory and Practice of Translation, London: Routledge.

SCHJOLDAGER, Anne. 2008. Understanding Translation. Academica, Arlus.

SHAROFF, S., BABYCH, B and HARLLY. T. 2006. "Using Comparable Corpora to Solve Problems Difficulties for Human Translators". In ACLIHLT, 2006.

TROSBOR, Anne. 1997. "Text Typology: Register, Genre and Text Type." In: Trosborg, Anne (Ed). 1997 Text Typology and Translation. John Benjamin Publishing Company, Amsterdam.

VENNUTI, L. 2000. The Translation Studies Reader. London: Routledge. 